\title{
Landslides Articulation in Wadi Hof Area Southeast of Cairo, Egypt, Based on Geological and Geophysical Investigations
}

Ahmed M Abd El-Gawad ( $\nabla$ ahmedm@sci.asu.edu.eg )

Faculty of Science, Ain Shams University

\section{Research}

Keywords: Landslides, Geological, Geophysical, Eocene aquifer, Wadi Hof, Egypt

Posted Date: August 27th, 2020

DOI: https://doi.org/10.21203/rs.3.rs-44970/v1

License: (9) This work is licensed under a Creative Commons Attribution 4.0 International License. Read Full License

Version of Record: A version of this preprint was published on February 27th, 2021. See the published version at https://doi.org/10.1007/s12665-021-09478-w. 


\section{Abstract}

Detailed field geological, geoelectrical, hydrochemical, and microbiological studies were executed in Wadi Hof area, southeastern Cairo, Egypt to delineate the causes of landslides along the train pathway between the eastern Wadi Hof camp and the western clay quarry. The area under consideration is of low relief and gentle slope from east to west, the rock sloping is unstable and represent potential areas of rock failure in several locations. The Eocene limestone rocks constitute the most common outcrops. Structurally, the investigated area was affected by faulting. Geophysically, vertical electrical soundings in addition to horizontal profiling techniques were surveyed to know the shallow subsurface implications. Moreover, Hydrochemical and microbiological investigations in the form of water samples analysis east and west to the train pathway. The integrated interpretations exhibited that, the study area consists of three main units; surface marl; calcareous sand, and finally clay to sandy clay units. The water originates from the Eocene limestone aquifer east of the train route directed to the clay quarry west of the train path. Added, the landslides are resulted due to the clay swelling followed by railway destruction in a short time due to the large clay thicknesses.

\section{Introduction}

The present work aims to find out the water origin that has collected at the floor of the clay quarry to the west of the train pathway, and led to landslides and damage of train path trajectory between the eastern Wadi Hof camp and western clay quarry, as well as, to shed the light on the geological conditions prevailing in this particular area. The study area is located to the east of the River Nile, about $16 \mathrm{~km}$ to the southeast of Cairo with an average elevation of about 50 meters above mean sea level. It extends between latitudes $29^{\circ} 54 \times 31.5 \square$ and $29^{\circ} 54 \times 57.5 \bigotimes$ North and longitudes $31^{\circ} 18 \times 07.1 \rrbracket$ and $31^{\circ} 18 \times 46.1 \rrbracket$ East (Fig. 1). The considered area is arid to semi-arid climatic conditions; warm in winter with scare rain and hot to dry in summer. Geomorphologically, the study area is subdivided from east to west into the plateau, escarpments, cliffs, terraces, and the Nile Flood plains. The slopes of the Middle Eocene rocks are unstable and represent potential areas of rock failure in many places (Yousif, 2000). The structural plateau which consists mainly of limestone is dissected by several faults, the piedmont plain and the Nile flood plain are formed by a tectonic depression (Henaish and Kharbish, 2020). The study area was subjected to three sets of faulting systems orienting mainly in NE-SW, E-W, and NW-SE directions (Moustafa et al., 1985). The general groundwater flow direction is to northward and westward directions towards the Nile River. The significant amounts of limestone and clay quarrying activities are considered as the most important factors of water seepages and landslides (Abd El Gawad and Gamal 2008; Abd El Gawad et. al., 2017). Hydrogeologically, the fissured and cavernous Eocene limestone aquifer represent the main aquifer in the study area. The quarrying activities in the western parts of the train railway play an important role in the instability of the Middle Eocene rocks slopes which represent potential sites of slope failure (Abd El Gawad, 2020). Added, due to systems of vertical and horizontal joints, the water can percolate through the open joints, thus creating a seepage trail. Accordingly, the field investigations showed that a considerable landslide under the train pathway and on the floor of the clay quarry in addition to several water pools are distributed randomly (Fig. 2). 


\section{Methods Of Studies}

Detailed field geological inspections in addition to geoelectrical, hydrochemical, and microbiological investigations ware surveyed and executed in and around the area under consideration with special emphasize on the east and west the train pathway.

\subsection{Geological Fieldwork}

According to precise field observations, it is noted that random distributions of vegetations grew at the top of the clay quarry in addition to the camp which gives a primary impression about the source of water that drains from the limestone plateau. Added, the ground elevations of the fore-mentioned vegetations range from 22 m., 29 m., 34 m., 44 m., to 45 above sea level. Moreover, the rate of land-sliding in the past fifteen years was studied in detail from 2003 to 2018, This study is based on measuring distances between the train path location and the western border of landslides based on the historical view from Google Earth. The forementioned measurements cleared that the distance between the train path and the western border of landslides decreased gradually and then abruptly from June 2003 to May 2018 which emphasizes finally the complete damage of the train path.

\subsection{Geoelectrical Resistivity Work}

The geoelectrical resistivity method was executed in the form of 1D Schlumberger Vertical Electrical Sounding (VES) and 2D Electrical Resistivity Tomography (ERT) using Wenner array. Eight vertical electrical soundings were measured along with two main profiles-oriented northeast-southwest directions (Figure 3). Each profile represents four vertical electrical soundings, the train path located nearly parallel to the two measured profiles and between them. Schlumberger configuration of electrode separation starting from electrode separations $(A B \backslash 2)=1.5 \mathrm{~m}$. to $A B \backslash 2=200 \mathrm{~m}$. is applied. Some outcropping geological sections near some measured vertical electrical soundings are selected and used for correlations between the electrical resistivity data and the real geological data. The method used to convert the measured values of electrode separations ( $A B \backslash 2)$ and apparent resistivities ( $\square$ a) into a multi-layer model is that of Zohdy (1989). The inversion is applied by using WinSev3.4 software followed by the establishment of the geoelectrical cross-sections. The interpretation results of the measured vertical electrical soundings are shown in Table (1) and illustrated in Figure (4).

Table (1) Interpreted geoelectrical resistivity field data of the study area 


\begin{tabular}{|llllllll|}
\hline AB/2 (m.) & $\square_{1}(\mathbb{m})$. & $\square_{2}(\mathbb{m})$. & $\square_{3}(\mathbb{m})$. & $\square_{4}(\mathrm{~m})$. & $\mathrm{h}_{1}(\mathrm{~m})$. & $\mathrm{h}_{2}(\mathrm{~m})$. & $\mathrm{h}_{3}(\mathrm{~m})$. \\
\hline VES 1 & 2400 & 280 & 8.4 & 18 & 0.79 & 14 & 55 \\
VES 2 & 2900 & 340 & 11 & 21 & 0.61 & 12 & 56 \\
VES 3 & 42 & 220 & 9 & 16 & 1.3 & 13 & 56 \\
VES 4 & 660 & 180 & 11 & 11 & 4 & 13 & 55 \\
VES 5 & 8246 & 210 & 11 & 11 & 4.6 & 11 & 53 \\
VES 6 & 540 & 240 & 11 & 6 & 0.5 & 13 & 55 \\
VES 7 & 400 & 110 & 8.6 & 17 & 1.8 & 13 & 54 \\
VES 8 & 410 & 170 & 11 & 11 & 0.7 & 11 & 55 \\
\hline
\end{tabular}

The geoelectrical cross-sections can outline the thicknesses and electric resistivities values characterizing the inherited geoelectrical units. Two geoelectrical cross-sections oriented nearly northwest-southeast were constructed to cover the study area. The geoelectrical cross-section A-A (Figure 5) and B-B (Figure 6) are represented by three geoelectrical units as follows: The first (surface) unit is characterized by relatively moderate to high electrical resistivity values and small thickness, which corresponds to the surface marl unit. The second unit is recognized by relatively moderate electrical resistivity values ranged between and medium thickness, which corresponds to the calcareous sand unit. The third unit is characterized by relatively low electrical resistivity value and larger thickness which corresponds to the clay-sandy clay unit.

The Electrical Resistivity Tomography (ERT) profiles are better lateral and vertical resolutions if they compared with vertical electrical sounding. In the area under consideration, three 2D Electrical Resistivity Tomography profiles crossing the train pathway were constructed in a nearly east-west direction (Figure 7 $a, b$ \& c), with an electrode spacing of $4 \mathrm{~m}$., a length of $112 \mathrm{~m}$. and an average depth of penetration of 11 $\mathrm{m}$. The 2D ERT profiles were computed using the RES2DINV computer software, which is designed automatically to set up two-dimensional resistivity models of the shallow subsurface (Griffiths and Barker 1993). This software program was performed to invert large data sets collected by a large number of electrodes (Loke 1999). The three interpreted Electrical Resistivity Tomography profiles showed almost the same geoelectrical characteristics. These profiles showed an upper surface marl unit with relatively high resistivity, overlies a lower resistivity unit of sandy limestone, and finally lowest resistivity layer of clay and sandy clay layer.

\subsection{Water Analysis}

The chemical characteristics of water play an important role in the geologic history of the enclosing rocks, sources of recharge, velocity, and direction of water movement. Two water samples were taken from the area under investigation; the first one was taken east of the train pathway, from the camp water sewage 
station and the second one was taken west of the train pathway, from the clay quarry water flowing from the direction of the camp on their way to the clay quarry. These waters were samples carefully under precautions and analyzed chemically and microbiologically. The chemical analysis includes the major cations $\left(\mathrm{Ca}^{+2}, \mathrm{Mg}^{+2}, \mathrm{Na}^{+1} \& \mathrm{~K}^{+1}\right)$ and the major anions $\left(\mathrm{CO}^{-2}, \mathrm{HCO}^{-1}, \mathrm{SO}^{-2} \& \mathrm{Cl}^{-1}\right)$ expressed in ppm $(\mathrm{mg} / \mathrm{L})$ in addition to the total dissolved solids (T.D.S.) expressed in $\mathrm{ppm}$. While the microbiological analysis was done for Fecal bacteria (E. coli count).

Hydrochemically, the water sample taken from the clay quarry is characterized by relatively high TDS as well as the water type is sodium sulfate $\left(\mathrm{Na}^{+1}>\mathrm{Ca}^{+2}>\mathrm{Mg}^{+2}\right.$ and $\left.\mathrm{SO}^{-2}>\mathrm{Cl}^{-1}>\mathrm{HCO}^{-1}\right)$ while the water sample taken from the camp is of relatively low TDS and the water type is sodium carbonate. It is important to mention that, the analyzed two water samples are completely different in nature and origin which indicates that two water samples are of different sources. Added the microbiological analysis also supports this conclusion because the water samples that were taken from the camp contains fecal bacterial (E. coli) and count $25^{\star} 10^{2} \mathrm{cfu} / \mathrm{ml}$ where that of clay quarry contains no fecal bacterial (Table 2 ).

\section{Table ( 2 ) Water chemistry and microbiological analysis of two water samples}

\begin{tabular}{|c|c|c|c|c|c|c|c|c|c|c|}
\hline \multirow{2}{*}{$\begin{array}{l}\text { Water } \\
\text { Sample }\end{array}$} & \multicolumn{4}{|c|}{ Major Cations (ppm) } & \multicolumn{4}{|c|}{ Major Anions (ppm) } & \multirow{2}{*}{$\begin{array}{l}\text { TDS } \\
\text { (ppm) }\end{array}$} & \multirow{2}{*}{$\begin{array}{l}\text { Fecal } \\
\text { bacterial } \\
\text { (E. coli) } \\
\text { count }\end{array}$} \\
\hline & $\mathrm{Ca}^{+2}$ & $\mathrm{Mg}^{+2}$ & $\mathrm{Na}^{+1}$ & $\mathrm{~K}^{+1}$ & $\mathrm{CO}_{3}{ }^{-2}$ & $\mathrm{HCO}_{3}^{-1}$ & $\mathrm{SO}_{4}^{-2}$ & $\mathrm{Cl}^{-1}$ & & \\
\hline $\begin{array}{l}\text { Quarry } \\
\text { Sample }\end{array}$ & 331 & 147.5 & 431.25 & 16.38 & 100 & 170 & 1400 & 750 & 3500 & Absence \\
\hline $\begin{array}{l}\text { Camp } \\
\text { Sample }\end{array}$ & 46.33 & 13.08 & 44.88 & 12.73 & 160 & 290 & 98 & 97 & 800 & $\begin{array}{l}\text { Presence } \\
25 * 10^{2}\end{array}$ \\
\hline
\end{tabular}

\section{Results And Discussions}

By discussing the results of the geological, geophysical, hydrochemical and microbiological studies, the following results were reached; field geological studies have proven that there are plant collections that exist at various heights on the mountain and also in the clay quarry. This gives an indication that the water comes from the east up the mountain and heading to the west towards the clay quarry, and this has been proven from field observations in the study area. Also, by discussing the results of geophysical studies in the study area, it was noticed that there is no contention in the sequences of geoelectrical units horizontally or vertically east and west of the railway tracks, in addition to the presence of a large thickness of the clay, it led to its saturation with water and resulted in landslides along the railway tracks. Moreover, in terms of analyzes of water samples, hydrochemically and microbiologically, east and west of the train road. The analysis showed that the water sample taken from the sanitation of the camp east of the train road is completely different from those of the sample taken from the water west of the train road, and therefore confirmed that the water that falls from the east in the direction of the west is responsible for the landslides and that the water taken from the sewage do not leak into the quarry. Furthermore, the landslides which occurred along the tracks of the train were caused mainly by the Eocene limestone 
aquifer. Therefore, the expected flow direction (Fig. 8) should be from the highlands towards the lowlands (i.e., towards the Nile).

\section{Conclusion}

The fissured and cavernous Eocene aquifer in the eastern parts of the study area represents the main source of water responsible for the landslides along the train track. The cause of landslides is due to the swelling of clay followed by damage in a very short time due to the large thicknesses of clay units. The present study also indicated that the landslides are not stoppable and invade camp direction; the rate of landslides is very fast, especially within the last few years.

\section{Declarations}

\section{DATA AVAILABILITY STATEMENT}

With respect to the data availability, the author declares that all data supporting the findings of this study are available within the article itself. The author measured by himself all the vertical electrical resistivity sounding data in addition to the horizontal resistivity profiles.

\section{COMPETING INTERESTS}

The authors declare that they have no competing interests

\section{FUNDING}

The research article is not funded.

\section{AUTHORS' CONTRIBUTIONS}

The research is single author "Ahmed Abd El Gawad"

\section{ACKNOWLEDGEMENTS}

Not applicable

\section{References}

1. Abd El-Gawad A. M. S., 2020: Water seepage source at the extension of Tourah clay quarry, southeastern Cairo based on geological and geoelectrical resistivity measurements. Earth Sciences. Vol. 9, No. 3, pp. 108-116. doi: 10.11648/j.earth.20200903.13

2. Abd El-Gawad A.M.S., and Hossam G., 2008: Application of geoelectrical measurements to detect the ground-water seepage in limestone quarry of Helwan, southeastern Cairo, Egypt. $4^{\text {th }}$ International Conference on the Geology of the Tethys, Cairo Univ., Nov., pp. 141-148. 
3. Abd El-Gawad A.M.S., Helaly A.S. and Abd El-Latif M.S.E. (2018) Application of geoelectrical measurements for detecting the ground-water seepage in clay quarry at Helwan, southeastern Cairo, Egypt, NRIAG Jour

4. Griffiths D.H. and Barker R.D., 1993: Two-dimensional resistivity imaging and modeling in areas of complex geology. J Appl Geophys 29: 211-226

5. Henaish A. and Kharbish S., 2020: Linkage Style of Rift-Associated Fault Arrays: Insights from Central Cairo-Suez District, Egypt. Carpathian Journal of Earth and Environmental Sciences, Vol. 15, No.1, p. 189-196; doi:10.26471/cjees/2020/015/121

6. Loke M.H., 1999: Electrical imaging surveys for environmental and engineering studies: a practical guide to 2D and 3D surveys, Austin, Texas, Advanced Geosciences Inc.,57 p.

7. Moustafa A.R., Yehia M.A., and Abdel Tawab S., 1985: Structural setting of the area east of Cairo, Maadi, and Helwan. Middle East Research Center, Ain Shams Univ., Earth Science Series, 5, 40-64.

8. Sallam E., Issawi B. and Osman R., 2015: Stratigraphy, facies, and depositional environments of the Paleogene sediments in Cairo-Suez district, Egypt. Arabian Journal of Geosciences, 8 (4), 1939-1964.

9. Yousif, M.S.M., 2000: Slope Stability of the Middle Eocene Rocks of Gebel Mokattam ICEHM, Cairo University, Egypt, September 2000, pp.14-32

10. Zohdy, A. A. R, 1989: A new method for the automatic interpretation of Schlumberger and Wenner sounding curves. Geophysics. 54, 245-253.

\section{Figures}




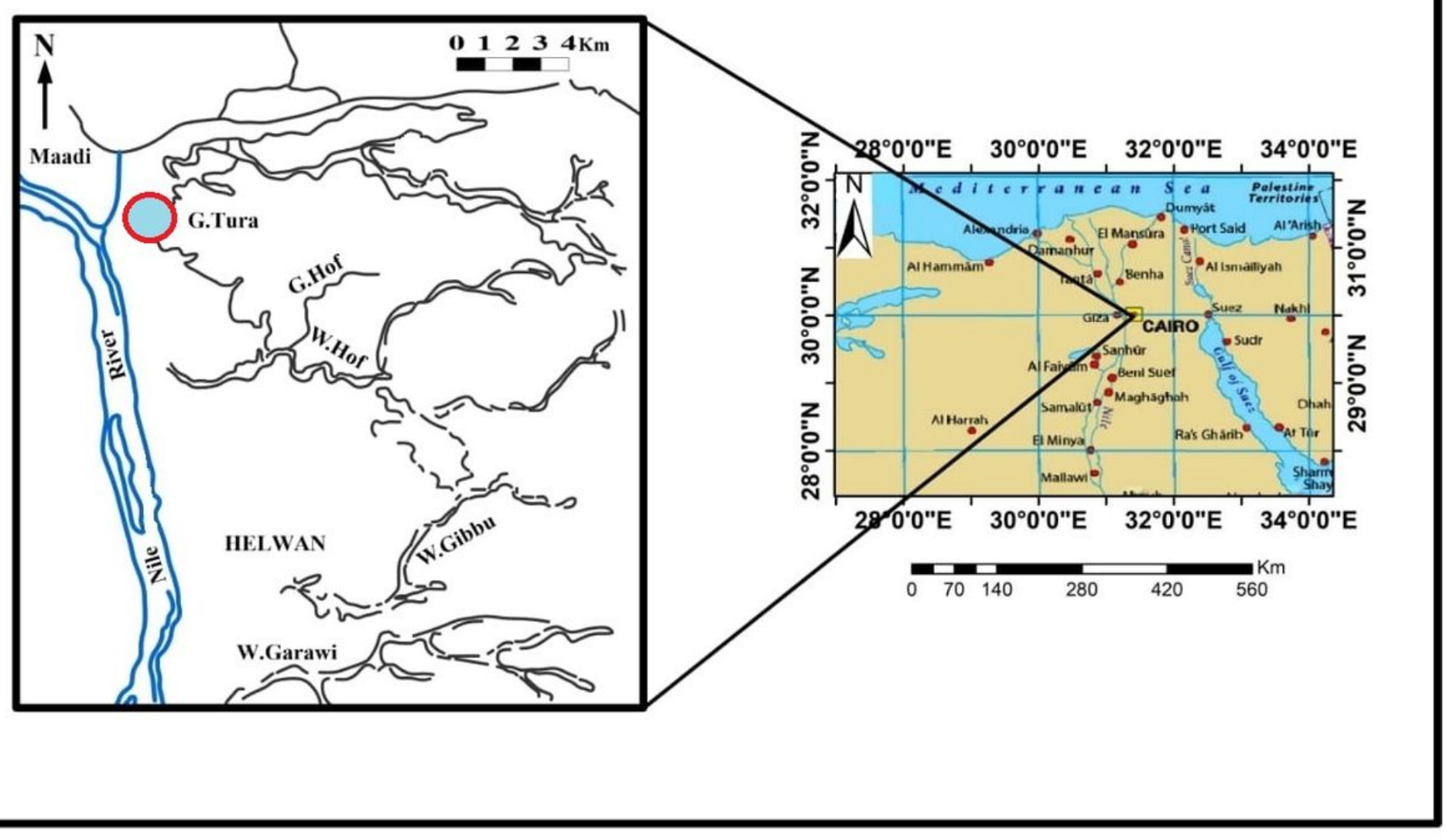

Figure 1

Figure 1 


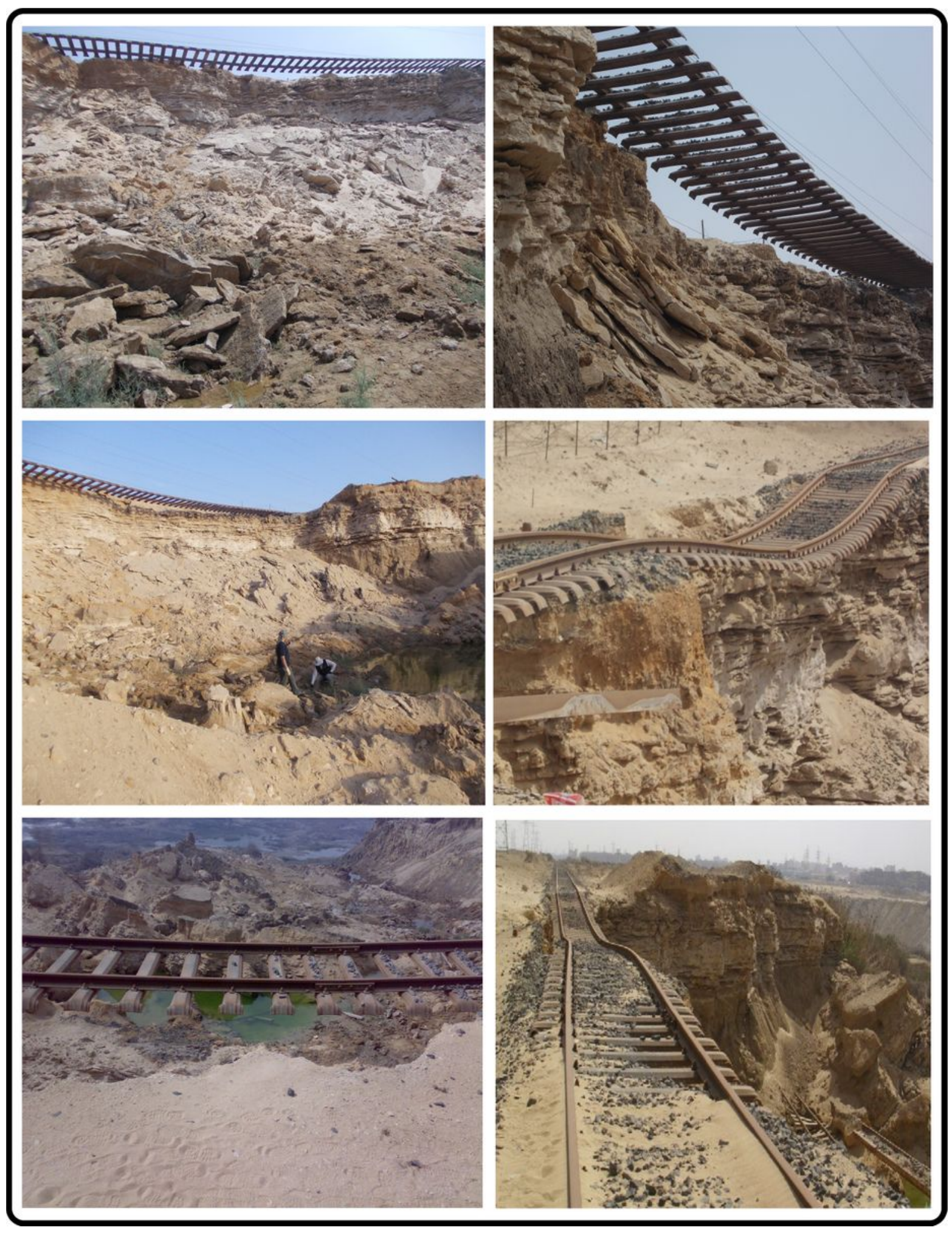

Figure 2

Figure 2 


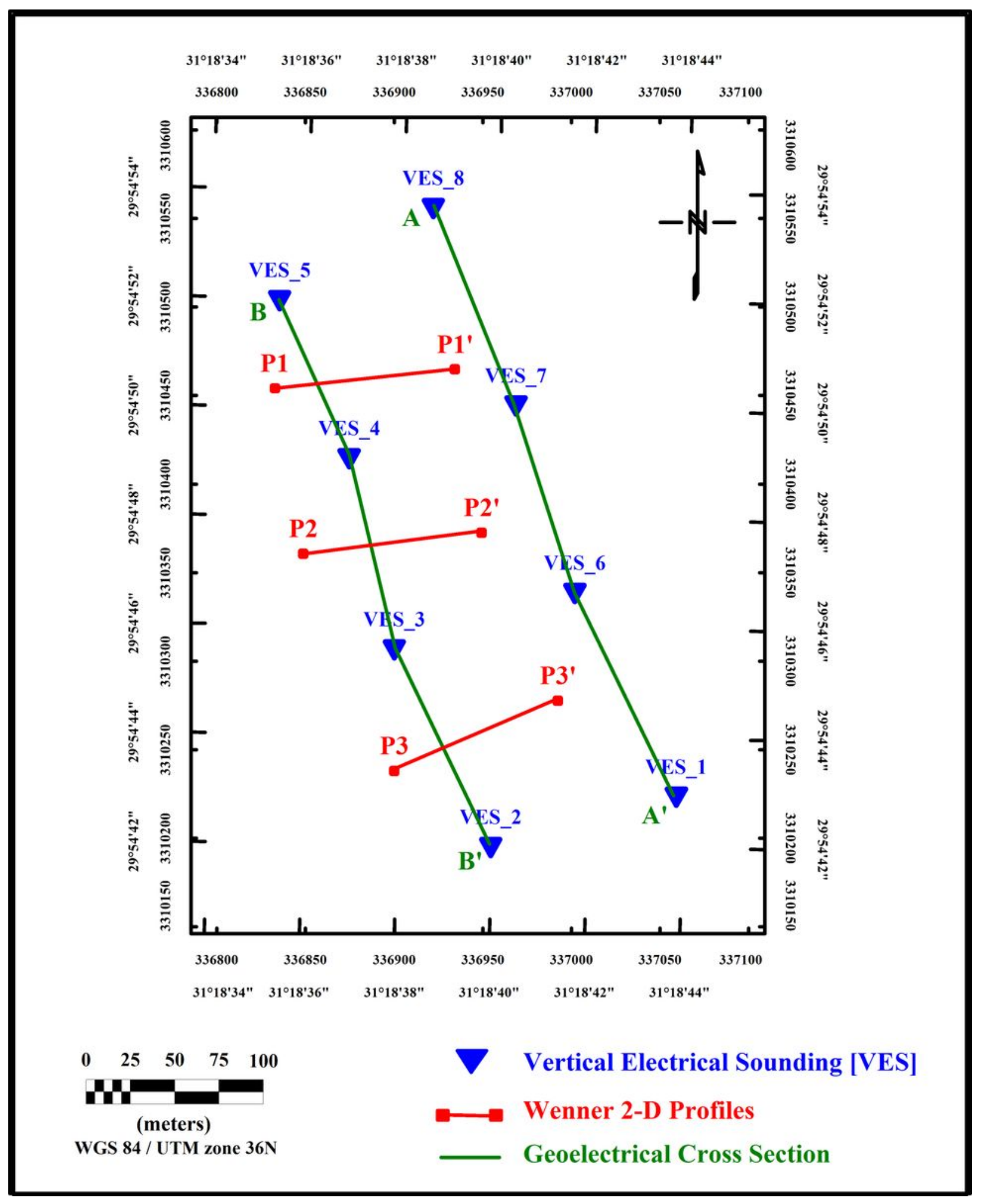

Figure 3

Figure 3 


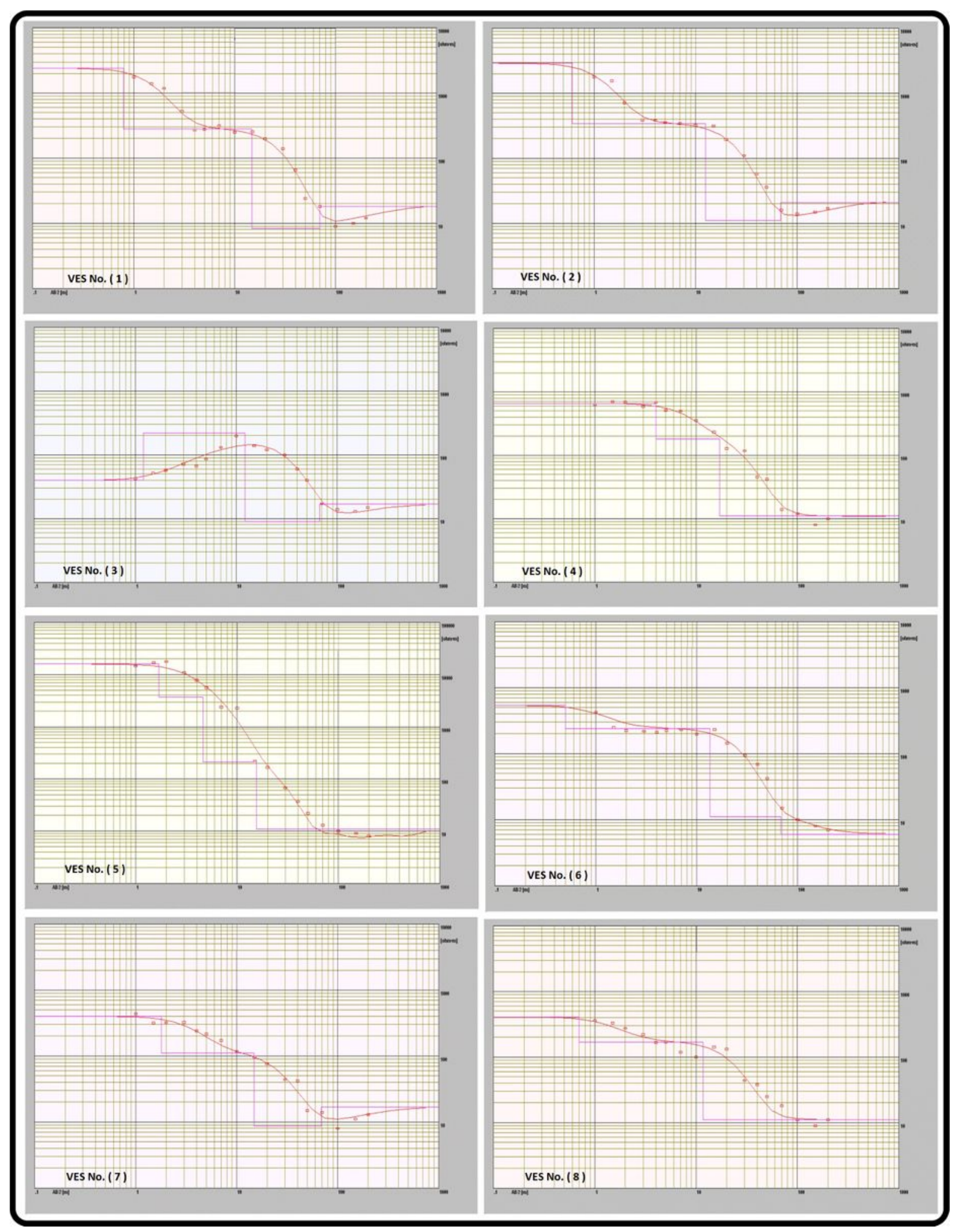

Figure 4

Figure 4 


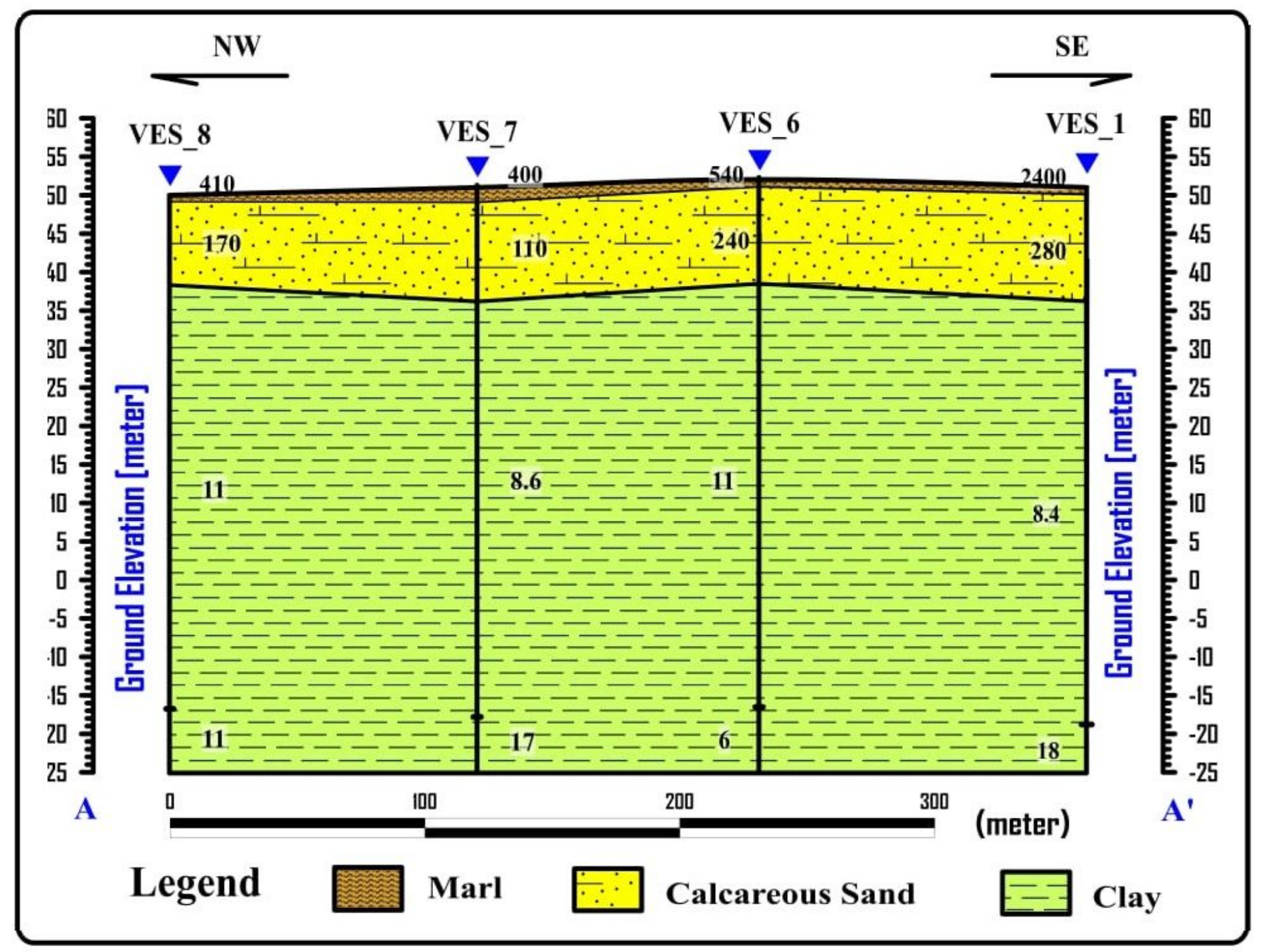

Figure 5

Figure 5 


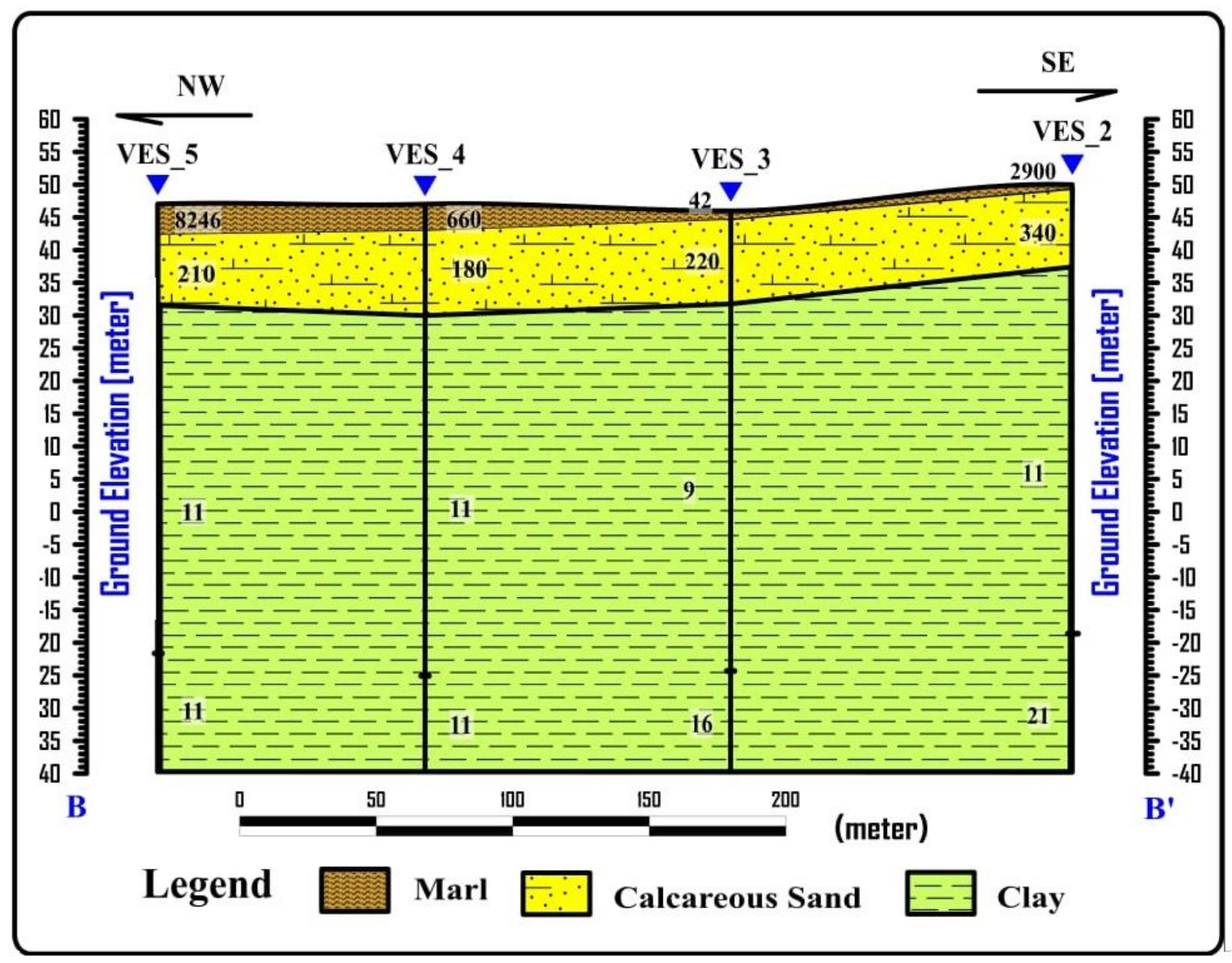

Figure 6

Figure 6 


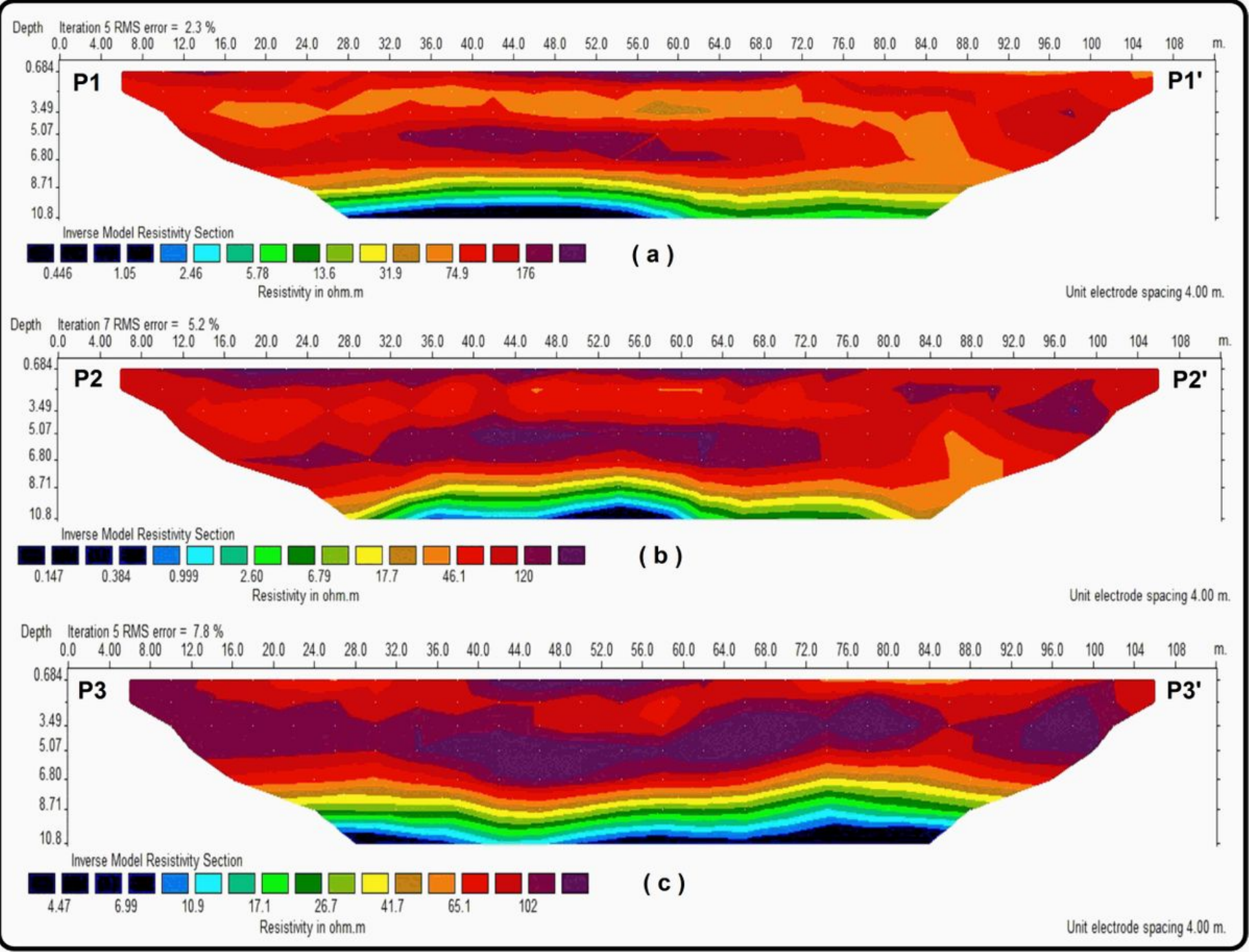

\section{Figure 7}

Figure 7 


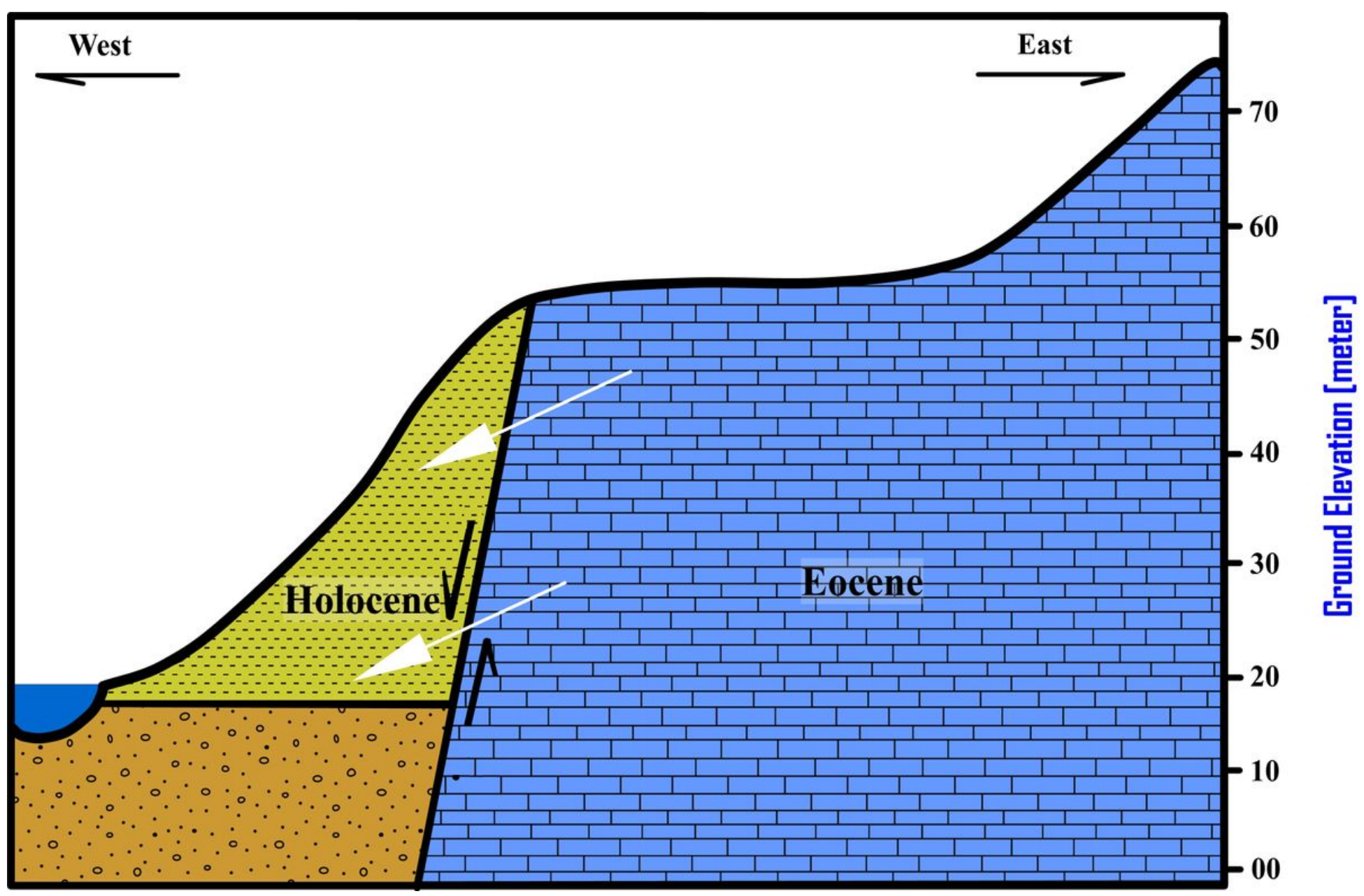

Figure 8

Figure 8 